\title{
DGH Delegationsreise zum 13. Triennal Congress der Chinese Society for Surgery of the Hand (CSSH) nach Qingdao in China
}

\author{
Representative mission of the German Society of Hand Surgery DGH to the $13^{\text {th }}$ Triennial \\ Congress of the Chinese Society for Surgery of the Hand (CSSH) in Qingdao, China
}

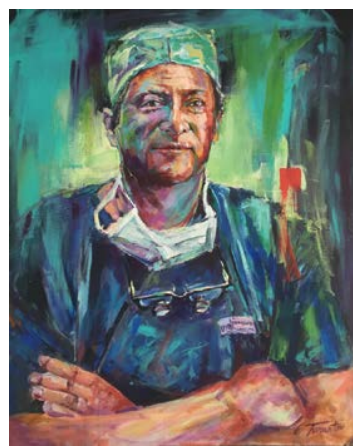

Univ.-Prof. Dr. med. Riccardo E. Giunta

Bibliography

DOI http://dx.doi.org/

10.1055/s-0042-109178

Handchir Mikrochir Plast Chir

2016; 48: 195-198

(c) Georg Thieme Verlag KG

Stuttgart · New York

ISSN 0722-1819

\section{Correspondence}

Univ.-Prof. Dr. med. Riccardo

\section{E. Giunta}

Abteilung für Handchirurgie

Plastische Chirurgie und

Ästhetische Chirurgie

Klinikum der Ludwig-

Maximilians

Universität (LMU) München

Pettenkoferstraße 8a

80336 München

r.giunta@med.uni-muenchen.de
Liebe Leserinnen und Leser,

die internationale Vernetzung ist seit langem ein wichtiges Element zum erfolgreichen weltweiten Wissenstransfer in der Handchirurgie und Plastischen Chirurgie. Informationen am „Cutting Edge of Science“ werden auf internationalen Kongressen, im direkten akademischen Austausch und durch Delegationsreisen, die direkte Kooperationen intensivieren oder neu eröffnen können, gewonnen. Auch für die Universitäten ist die internationale Vernetzung ein wesentliches Element der strategischen Ausrichtung gerade im Hinblick auf die Gewinnung der besten Wissenschaftler weltweit für unsere Universitäten in Deutschland.

Gerade für die Deutsche Gesellschaft für Handchirurgie (DGH) ist die internationale Öffnung im Hinblick auf deren Ausrichtung des 14. Kongresses der International Federations of Societies für Surgery of the Hand (IFSSH) 2019 in Berlin von zentraler Bedeutung. Erst im Januar dieses Jahres hatte Michael Sauerbier aus Frankfurt am Main eine Delegationsreise nach Scottsdale in Arizona zur AASH Tagung organisiert und damit unsere Vernetzung in die USA entscheidend gestärkt [1]. Auf dem Weg zur IFSSH Tagung 2019 in Berlin wird die diesjährige 57. Jahrestagung der DGH in Frankfurt am Main im Gegenzug eine Delegation aus den USA empfangen. 2015 hatte Max Haerle eine gemeinsame Tagung mit der italienischen Gesellschaft Societá Italiana per Chirurgia della Mano (SICM) erfolgreich organisiert und 2016 werden wir hier in München die 58. Jahrestagung der DGH die englische Gesellschaft für Handchirurgie (BSSH) zu Gast haben, um den internationalen Wissenstransfer zu befördern.

\section{Deutsche Medizin in China}

Westliche Medizin wurde in China vor allem auch durch Deutsche Ärzte Ende des 19. Jahrhunderts in China verbreitet. Medizin und medizinische Ausbildung genießt seither in China ein hohes Ansehen [2]. Aus einer Gemeinschaftspraxis von 5 deutschen Ärzten ging bereits 1899 ein Krankenhaus unter deutscher Leitung in Shanghai hervor, das 1904 den Namen Tung-Chee (Tung-Chi, später Tongji) trug, was im Shanghaier Dialekt soviel wie „deutsch“ bedeutet [3]. Daraus ging 1907 die „Deutsche Medizinschule für Chinesen" hervor. 1916 hatte diese Medizinschule bereits 204 Schüler. Mit steigenden Schülerzah-
Dear Readers,

International networking has long been a crucial element for a successful global transfer of knowledge in the fields of hand surgery and plastic surgery. Information at the "cutting edge of science" is gathered at international congresses, through direct academic exchange and through representative missions, which may intensify existing collaborations or open up new ones. For universities, too, international interconnection is an essential strategic element, especially when it comes to winning over the best scientists worldwide for our universities in Germany.

International opening is of central importance for the German Society of Hand Surgery ("Deutsche Gesellschaft für Handchirurgie”, DGH), which will organise the $14^{\text {th }}$ Congress of the International Federations of Societies for Surgery of the Hand (IFSSH) in Berlin in 2019. In January of this year, Michael Sauerbier from Frankfurt on the Main, Germany, organised a representative mission to the AASH meeting in Scottsdale, Arizona, USA, thereby significantly strengthening our interconnectedness in the United States. [1] In return, and with a view to the IFSSH meeting in Berlin in 2019, a US delegation will be welcomed at this year's $57^{\text {th }}$ Annual Meeting of the DGH in Frankfurt on the Main. In 2015, Max Haerle successfully organised a joint meeting with the Italian society Societá Italiana per Chirurgia della Mano (SICM), and in 2016 we will be host to the British Society of Hand Surgery (BSSH) at the $58^{\text {th }}$ Annual Meeting of the DGH here in Munich in order to promote the international transfer of knowledge.

In China, Western medicine was mainly propagated by German doctors at the end of the $19^{\text {th }}$ century. Ever since that time, medicine and medical education have been held in high esteem in China. [2] In 1899, a Shanghai group practice of 5 German doctors developed into a Germanmanaged hospital. In 1904, the name of that hospital was Tung-Chee (Tung-Chi, later: Tongji), which means "German" in the dialect of Shanghai. [3] The hospital evolved into the "German School of Medicine for Chinese Students" in 1907. In 1916, the medical school had a many as 204 students. With the numbers of students rising, the medical school, along with the faculty of engineering, was conferred the rank of a university by the Ministry of Education in 1924. The People's Republic of China was founded in 1949, 
Tab. 1 Deutsche-Chinesisch Aktivitäten der Abteilung für Handchirurgie, Plastischen Chirurgie und Ästhetischen Chirurgie der Ludwig-Maximilians Universität München seit 2011 [2].

- 2011-2015 Shenyu Lin im Rahmen des CSC Promotions im Rahmen des CSC des Ludwig-Maximilians Universität

- 2013 Delegationsreise des International Offices der Ludwig-Maximilians Universität München unter der Leitung von Dr. Lauterbach an der Fudan und jiatong Universität Shanghai

- 2013 Vortrag und Besuch des $9^{\text {th }}$ People Hospital unter der Leitung von Prof. Quinfeng Li

- 2013 Unterzeichnung Memorandum of Understanding im Ruijin hospital der jiao Tong Universität

- 2013 Besuch Prof. Gu im Huashan Hospital der Fudan University

- 2014 Delegationsbesuch von Prof. Zhengbing Chen, Professoren Jianhai Chen und und Dr. Huaiyuan Zheng aus Wuhan der Abteilung für Handchirurgie, Plastische Chirurgie und Ästhetische Chirurgie der LMU München

- 2014 Reconstruction of Complex Defects after Trauma and Tumor - Sino-German Network Meeting on Advances in Basic Science and Clinical Strategies im Rahmen der 45. Jahrestagung der DGPRÄC in München gefördert durch das Chinesisch-Deutsche Zentrum für Wissenschaftsförderung (CGS)

- 2015 Vortrag und Besuch von Prof. Kai Liu vom $9^{\text {th }}$ People Hospital Shanghai an der der Abteilung für Handchirurgie, Plastische Chirurgie und Ästhetische Chirurgie der LMU München

- 2015 Delegationsbesuch der Shanghai jiaotong Medical School und des Renji Hospital an der LMU München

- 2015 Erstes LMU - China Academic Network (LMU-ChAN) in München

Tab. 2 Die DGH Delegationsteilnehmer zum 13. Triennal Congress der Chinese Society for Surgery of the Hand (CSSH) nach Qingdao.

- Dr. Eva Baur, Murnau

- PD Dr. Björn Behr, Bochum

- Prof. Andreas Eisenschenck, Berlin

- Prof. Riccardo Giunta, München

- Dr. Rolf Habenicht, Hamburg

- Dr. Tanja Herrler, Murnau

- Prof. Karl-Josef Prommersberger, Bad Neustadt/Saale

- Prof. Martin Jung, München

- Dr. Sebastian Kluge, Zürich

- Dr. Stefan Lauterbach, München

- Prof. Günther Machens, München

- Dr. Ralph Nyszkiewicz, Hamburg

- Dr. Marin Richter, Bonn

- PD Dr. Susanne Rein, Halle

- Prof. Michael Sauerbier, Frankfurt am Main

- Prof. Michael Schädel-Höpfner, Neuss

- PD Dr. Frank Siemers, Halle

- Dr. Heinrich Tünnerhof, Marbach

- Prof. Jörg van Schoonhoven, Bad Neustadt/Saale

- Prof. Peter Vogt, Hannover

- PD Dr. Elias Volkmer, München

- Dr. Alexander Zach, Stralsund

len verlieh das Unterrichtsministerium der Schule 1924 gemeinsam mit den Ingenieurwissenschaften den Rang einer Universität. Die Volkrepublik China wurde 1949 gegründet und die Medizinische Fakultät zog nach Wuhan um und nannte sich fortan Tongji Hospital bzw. Tongji Medical University. Im Jahre 1979 wurde sie unter dem Vorsitzenden Deng Xiaoping wieder zur multidisziplinären Universität und hatte den Auftrag in allen Disziplinen Verbindungen zur Bundesrepublik Deutschland aufzubauen [3].

Mit China bestehen seit vielen Jahren exzellente Beziehungen die von direkten Delegationsreisen über den Austausch von Wissenschaftlern, gemeinsamen Forschungsprojekten bis hin zu gemeinsamen Kongressen reichen [2] ( $\bullet$ Tab. 1). Zuletzt hatten wir 2014 bei der 45. Jahrestagung der DGPRÄC (Deutsche Gesellschaft der Plastischen, Rekonstruktiven und Ästhetischen Chirurgen) bei uns in München ein Deutsch-Chinesisches Symposium mit dem Thema „Reconstruction of Complex Defects after Trauma and Tumor - Sino-German Network Meeting on Advances in Basic Science and Clinical Strategies“ organisiert. Das Chinesisch- Deutsche Zentrum für Wissenschaftsförderung (CGS) hatte dankenswerterweise die Fördermittel für diese wichtige Veranstaltung bereitgestellt und damit ermöglicht, dass $15 \mathrm{Kol}-$ legen aus ganz China Gelegenheit zu einem sehr fruchtbaren and the medical school moved to Wuhan and changed its name into Tongji Hospital or Tongji Medical University. In 1979, it was turned back into a multidisciplinary university under Chairman Deng Xiaoping and was commissioned to establish connections with the Federal Republic of Germany in all disciplines. [3] There have been excellent relationships with China for many years, ranging from direct representative missions to scientific exchange, joint research projects and joint congresses [2] (○ Tab. 1). In 2014, at the $45^{\text {th }}$ Annual Meeting of the DGPRÄC (German Society of Plastic, Reconstructive and Aesthetic Surgeons), a German-Chinese symposium was organised in $\mathrm{Mu}-$ nich, the topic being "Reconstruction of Complex Defects after Trauma and Tumour - Sino-German Network Meeting on Advances in Basic Science and Clinical Strategies“. The Sino-German Centre for Research Promotion (SGC) kindly provided the funding for this crucial event and enabled 15 doctors from across China to travel to Germany for a very fruitful exchange of knowledge and to establish future collaborations. [4] This was organised by my working group in Munich together with the Chief Physician of the Department of Hand Surgery at the Tongji Medical College in Wuhan, Professor Zhengbin Chen, $[2,4]$ with whom we have been in touch since my first trip to China in 2009. Since then, there have been further visits to Shanghai in 2013, including a visit to Professor Li from the Department of Plastic Surgery of the 9th People Hospital and a visit to Professor Gu at the Huashan Hospital of Fudan University. We used this opportunity together with Dr. Martin Lauterbach from the International Office of the Ludwig-Maximilians University in Munich to sign a Memorandum of Understanding with the Jiatong University in the Ruijin Hospital.

In return for the DGPRÄC meeting in 2014, we were invited to the $13^{\text {th }}$ Triennial Congress of the Chinese Society for Surgery of the Hand (CSSH) from May $11^{\text {th }}$ to May $14^{\text {th }}$ by the congress president, Professor Jie Lao from the Department of Hand Surgery at the Huashan Hospital in Shanghai. This invitation was initiated by Zhengbing Chen.

22 hand surgeons and plastic surgeons followed the call to Qingdao in the province of Shandong ( $\bullet$ Tab. 2, $\bullet$ Fig. 2). The meeting was attended by the current President of the DGH, Martin Richter from Bonn, Germany, Past President Rolf Habenicht from Hamburg, the Past President of the German Society of Surgery (DGCH) and the DGPRÄC, Peter Vogt, as well as the Secretary and Past President of the DGH, Jörg van Schoonhoven, and almost all members of the advisory board of the DGH ( $\bullet$ Fig. 1). More than 1200 participants from across China attended the congress of 


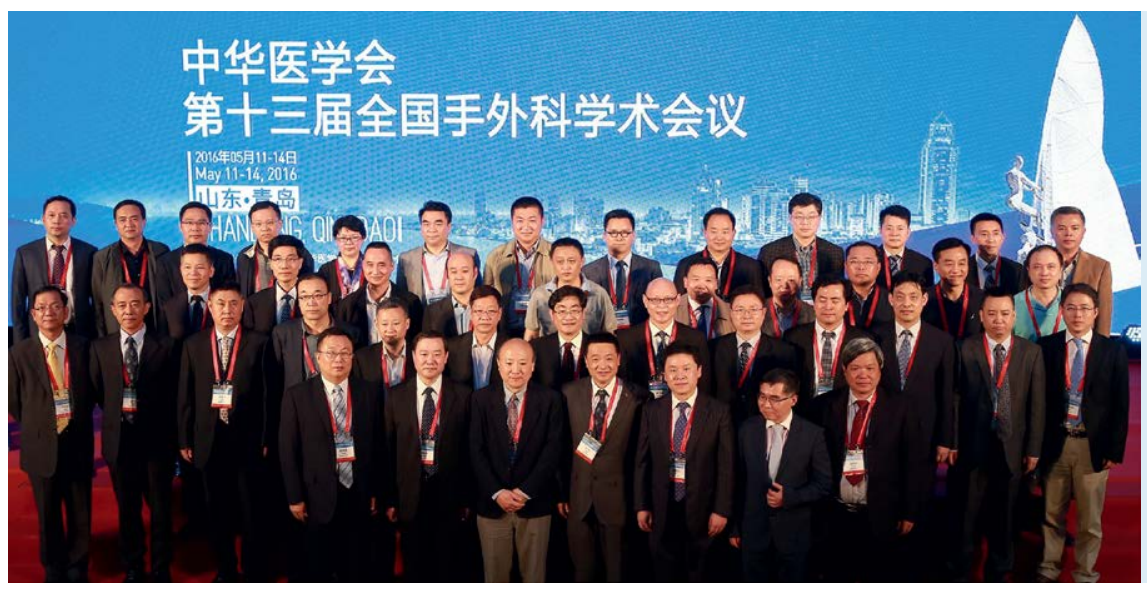

Abb. 1 Unsere chinesischen Gastgeber der CSSH: Unter anderen Past President Prof. Guanglei Tian aus Peking (Erste Reihe 3. von links), Präsident und Kongresspräsident Prof. Lao Jie aus Shanghai (erste Reihe, vierter von links), aktueller Präsident der CSSH Prof. Wengdong XU aus Shanghai (Erste reihe fünfter von links), Prof. Zhengbin Chen aus Wuhan (zweite Reihe, zweiter von rechts)

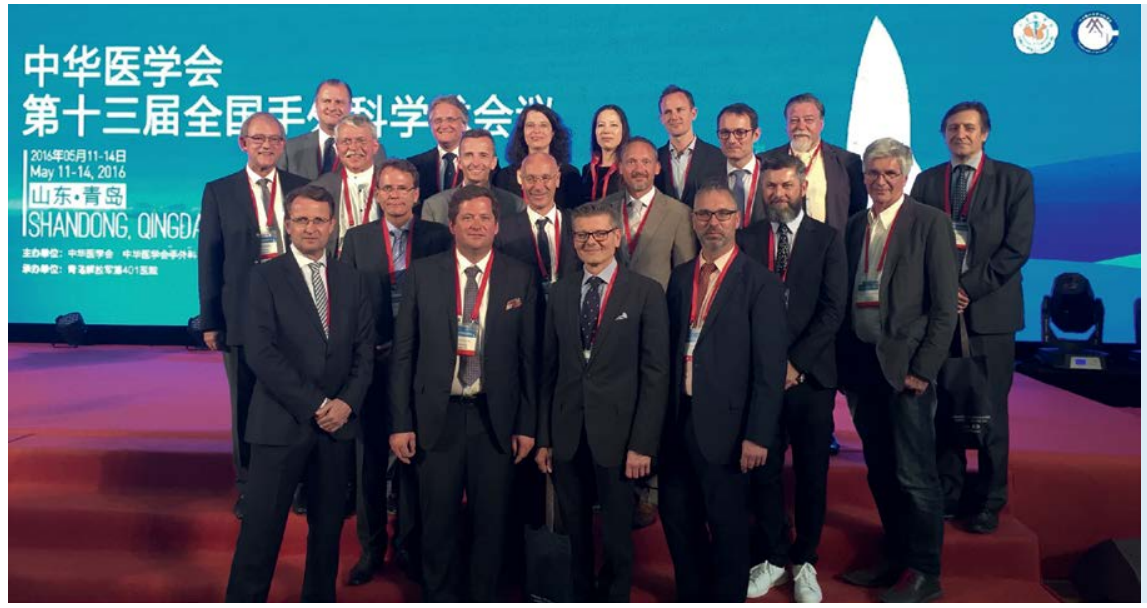

Abb. 2 Die DGH Delegation in Qingdao, China (von links nach rechts): Martin Richter, Günther Machens, Michael Sauerbier, Rolf Habe nicht, Andreas Eisenschenck, Karl-Josef Prommersberger, Michael Schädel-Höpfner, Riccardo Giunta, Susanne Rein, Jörg van Schoonhoven, Peter Vogt, Tanja Herrler, Alexander Zach, Elias Volkmer, Frank Siemers, Martin Jung, Sebastian Kluge, Heinrich Tünnerhof, Stefan Lauterbach.

Wissensaustausch und zum Aufbau von künftigen Kooperationen nach Deutschland reisen konnten [4]. Organsiert hatte meine Arbeitsgruppe in München dies gemeinsam mit dem Chef der Handchirurgie am Tongji Medical College in Wuhan Professor Zhengbin Chen [2,4], mit dem wir seit meiner ersten Chinareise 2009 im wechselseitigen Kontakt standen. In der Zwischenzeit gab es weitere Besuche in Shanghai 2013 in der Plastischen Chirurgie bei Prof. Li des $9^{\text {th }}$ People Hospitals sowie bei Prof. Gu in Shanghai im Huashan Hospital der Fudan University. Bei dieser Gelegenheit hatten wir auch gemeinsam mit Dr. Martin Lautenbach vom International Office der Ludwig-Maximilians Universität München ein Memorandum of Understanding im Ruijin Hospital mit der Jiatong University unterzeichnet. Im Gegenzug zur DGPRÄC Tagung 2014 hatte uns auf Initiative von Zhengbing Chen und zu Anlass des 13. Trienneal Congreses der Chinese Society for Surgery of the Hand (CSSH) vom 11. bis 15. Mai 2016 ( ( $\bullet$ Abb. 1) deren Präsident Prof. Jie Lao der Handchirurgie am Huashan Hospital in Shanghai eingeladen.

Dem Aufruf waren 22 Handchirurgen und Plastische Chirurgen nach Qingdao in der Provinz Shandong gefolgt ( $\bullet$ Tab. 2, ( $\bullet$ Abb. 2). Teilgenommen haben unter anderem der derzeitige Präsident der DGH Martin Richter aus Bonn, der Past President Rolf Habenicht aus Hamburg, der Past Präsident der Deutschen Gesellschaft für Chirurgie (DGCH) und der DGPRÄC Peter Vogt, sowie der Sekretär und Past President der DGH Jörg van Schoonhoven und fast alle Mitglieder des Beirats der DGH. Mehr als 1200 Teilnehmer aus ganz China haben am Kongress der CSSH teilgenommen. Mehr als 2200 Abstracts wurden eingereicht. 280 Vorträge wurden am Kongress diskutiert. the CSSH. More than 2200 manuscripts were received in this meeting and more than 280 surgeons gave the oral presentation. The harbour town of Qingdao in the province of Shandong was a German colony from 1898 to 1911 . The Chinese beer brand Tsingtao and numerous buildings are reminiscent of that time, and the "Paulaner Beer Garden" at the waterfront makes visitors from Munich feel at home instantaneously. The town of Quingdao, with an approximate 8 million inhabitants in the metropolitan area, became known internationally when it organised the sailing contests during the Olympic Games of Beijing in 2008. Due to the German influence on that town, we were invited as part of a representative mission to China. The congress was locally hosted by Professor Hou Shujian from the 401 Military Hospital in Qingdao. Direct organisational planning was provided beforehand by Dr. Huaiyuan Zheng. He tended to us together with his wife Dr. Juan Liu, who is currently working in the Department of Plastic Surgery at the Munich hospital "Klinikum rechts der Isar". Both of them went out of their way to cater for the needs and wishes of the delegation and, together with Professor Zhenbing Chen, made our congress trip to China unforgettable.

The congress covered traditional microsurgical topics such as the brachial plexus, free flap grafting, replantation surgery and transplantation as well as the topics of wrist surgery and congenital malformations. It started with a great Chinese-style opening event with multiple effects on the first day. For the following day we had organised a large joint session in English language with simultaneous interpretation for our Chinese col- 
Die Hafenstadt Qingdao in der Provinz Shandong ist ehemalige deutsche Kolonie (1989-1911). Aus dieser Zeit stammt die chinesische Biermarke Tsingtao und noch zahlreiche Gebäude. Als Münchner fühlt man sich gleich wohl, wenn man den Paulaner Biergarten am Ufer erblickt. Weltweite Bekanntheit hat die Stadt mit ca. 8 Millionen Einwohnern in der Metropolregion durch die Ausrichtung der Segelwettbewerbe während der Olympiade in Peking 2008 erlangt. Auf Grund des deutschen Einflusses auf die Stadt wurde wir auch als Delegation nach China eingeladen. Der lokale Gastgeber des Kongresses war Prof. Hou Shujian vom 401 Military Hospital in Qingdao. Die direkte organisatorische Planung hatte Dr. Huaiyuan Zheng vorab übernommen und uns gemeinsam mit seiner Frau Dr. Juan Liu, die derzeit in der Plastischen Chirurgie am Klinikum rechts der Isar in München tätig ist, übernommen. Beide haben sich hervorragend um die direkte Betreuung der Delegation gekümmert und uns gemeinsam mit Prof. Zhenbing Chen eine unvergessliche Kongressreise nach China beschert.

Kongressthemen waren traditionell mikrochirurgische Themen wie Plexus brachialis, freie Lappenplastiken, Replantationschirurgie und Transplantation sowie die Themen Chirurgie des Handgelenks und angeborene Fehlbildungen. Am ersten Tag gab es eine mit vielen Effekten großartig chinesisch inszenierte Eröffnungsveranstaltung. Am Folgetag hatten wir eine große gemeinsame Hauptsitzung in englischer Sprache mit Simulatanübersetzung für die chinesischen Kollegen organisiert. Bemerkenswert waren die überzeugenden Ergebnisse vom neuen Präsidenten des CSSH, Prof. Wen-Dong Xu vom Huashan Hospital der Fudan University in Shanghai. Bei zentralen Läsionen z.B. nach Apoplex zeigte er eine Fallserie, die mittels kontralateraler Transposition der Wurzel C7 des Plexus brachialis auf die betroffene Seite eine erhebliche Reduktion der Spastik und eine Wiedererlangung besser kontrollierter Bewegungsmuster der betroffenen oberen Extremität für die Patienten ermöglichte.

Der nächste Tag war den oben genannten Themen ganztägig gewidmet. Die deutsche Delegation hat im Wechsel mit Kollegen aus China die verschiedenen Themen dargestellt und unter chinesisch deutscher Moderation diskutiert. Die Sitzungen wurden in englischer Sprache abgehalten und die Dias zumeist zuvor in Mandarin übersetzt worden, damit die nicht englischsprachigen Kolleginnen und Kollegen aus China folgen konnten. Darüber hinaus gab es eine Simultanübersetzung für die chinesischen Kollegen. Viele weitere Vorträge haben zahlreiche für uns neue Aspekte dargestellt. Beispielsweise hat zum Thema Handgelenk Dr. Guo Yang vom Beijing Jishuan Hospital eine sehr schöne Studie zur finite Elemente Analyse des Os scaphoideum vorgestellt. Neben vielen spannenden medizinischen Themen, wurde von Herrn Dr. Lauterbach, dem Leiter des International Offices der Ludwig-Maximilians Universität München auch die internationale Strategie mit China vorgestellt. Unsere ehemalige Mitarbeiterin, Frau Dr. Tanja Herrler, hat die Weiterbildung in China aus ihrer mehr als 2-jährigen Erfahrung in Shanghai am $9^{\text {th }}$ Peoples Hospital dargestellt.

Insgesamt wurde die Delegationsreise von allen Seiten positiv bewertet und konnte neben dem wechselseitigen Wissenstransfer auch bestehende Kooperationen in China bestärken und neue befördern. Im Namen der Delegation der DGH möchte ich mich bei unseren chinesischen Kollegen für einen spannenden Kongress bedanken.

Riccardo Giunta als Delegationsleiter

München im Mai 2016 leagues. We were impressed by the conclusive results presented by the new President of the CSSH, Professor Wen-Dong Xu from the Huashan Hospital of the Fudan University in Shanghai. He demonstrated a case series in patients with central lesions, e.g. after a stroke, whose spasticity was significantly reduced and who regained a better control of movement patterns in the affected upper extremities through contralateral transposition of the C7 nerve root of the brachial plexus to the affected side.

The next day was entirely dedicated to the aforementioned topics. In turn with colleagues from China, the German delegation presented the different topics and discussed them under Chinese-German moderation. The sessions were held in English language with most slides having previously been translated into Mandarin for non-English-speaking colleagues from China. In addition, simultaneous interpretation was provided for the Chinese colleagues. A lot of other lectures demonstrated numerous aspects which were new to us. For instances, Dr. Guo Yang from the Beijing Jishuan Hospital presented a very informative study on the topic of wrist surgery covering the finite element analysis of the scaphoid bone. A lot of exciting medical topics were discussed, and Dr. Lauterbach, Head of the International Office of the Ludwig-Maximilians University in Munich, presented the international strategy with China. Dr. Tanja Herrler, our former staff member, gave a presentation on advanced medical training in China, drawing from more than 2 years of personal experience at the $9^{\text {th }}$ Peoples Hospital in Shanghai.

All in all, the representative mission received positive feedback from all sides. In addition to enabling a reciprocal transfer of knowledge, it served to strengthen existing and promote new collaborations in China. On behalf of the delegation of the DGH, I would like to thank our Chinese colleagues for this exciting congress!

Riccardo Giunta, head of the delegation Munich, May 2016

\section{Literatur}

1 Richter M, Bicker B. Bericht vom AAHS-Meeting Januar 2016 in Scottsdale, Arizona. Handchir Mikrochir Plast Chir 2016; 48: 120-122

2 Giunta RE. Chances of scientific and clinical cooperations in china. Handchir Mikrochir Plast Chir 2011; 43: 323-324 doi:10.1055/s-00311295465. Epub 2012 Jan 12

3 Lü Shu, Wang Weijang, Silvia Kettelhut. Kulturspuren der Deutschen in Shanghai.Shanghai Brilliant Publishing House; Shanghai: ISBN 9787-5452-0616-6/K-2002012

4 Giunta RE. Retrospect of conjoined German and Austrian Societies of Plastic Surgery Annual Meeting 2014 in Munich. Handchir Mikrochir Plast Chir 2014; 46: 323-324 doi:10.1055/s-0034-1395684. Epub 2015 Jan 7 